\title{
ULTRASTRUCTURE OF THE BOVINE SYNOVIAL MEMBRANE IN ONTOGENESIS
}

\author{
D. HORKÝ \\ Department of Anatomy, Histology and Embryology, University of Veterinary Science \\ 61242 Brno
}

Received October 19, 1983

\begin{abstract}
Horký, D.: Ultrastructure of the Bovine Synovial Membrane in Ontogenesis. Acta vet. Brno, 53, 1984: 107-117.

Ultrastructural studies of the synovial membrane have been made on tissue samples obtained from 3 bovine adult individuals aged 3 to 5 years and 4 individuals aged 246 to 271 days after fertilization. The material was collected partly from the carpal, partly from hip joint for both light and electron microscopic histology.

The synovial membrane is composed of specifically modified cells which can be differentiated in A and B type and of the intracellular substance on the basis of study of their submicroscopic structure. Subsynovial tissue is placed under the main synovial membrane.

In synovial membrane of adult individuals A-cells form a nearly continuous cover and in between them there are B-cells deposited in clusters. Numerous secretory granules are placed in their cytoplasm and in the projections there are bundles of cytoplasmic filaments. Connections of desmosome type are not formed between the cells and basal membrane is missing, too. Intercellular areas are filled with amorphous ground substance with a prevailing amount of aperiodic fibrils.

Synovial membrane has a similar arrangement during the fetal period. There are numerous B-cells which do not form clusters. The amount of organellae taking part on proteosynthesis in comparison with adult individuals is larger, giving evidence of their activity. Collagen fibrils were identified in these cells intracytoplasmatically as well as pervading through the cell membrane.

On the surface of an adult as well as fetal synovial membrane we observed regions uncovered by cells, so that the intercellular substance is in a direct contact with the joint cavity.
\end{abstract}

Synovial membrane, synovialocytes $A, B$, synovial matrix, synovial membrane surface.

Structure and function of the synovial membrane has been studied since long. The first reports have been published in the year 1743 (Hunter - see Stone 1947). Many authors were engaged in the microscopic structure of synovial membrane and described its function under normal and experimental conditions as well as pathological changes in animal and human material (see Jaffe 1972).

First electron microscopic studies on the synovial membrane of calf, dog and guinea-pig published Langer and Huth (1960); synovial membrane of a rabbit described Ghadially and Roy (1966), later Krey et al. (1976), Oryschak and Ghadially (1976); comparison of the synovial membrane ultrastructure in man, mice, rat, rabbit and guinea-pig described Linck and Porte (1978), a proof on the secretory function of synovial membrane cells worked out Okada et al. (1981) who demonstrated secretory granules in the B synovialocytes of mice, rat, guinea-pig, rabbit and of man. Differences in composition and synovial membrane ultrastructure by rat and man described Roy and Ghadially (1967) and in the first place Wassilev (1972, 1973, 1975). Cutlip and Cheville (1973) presented a fundamental description on sheep.

Langer and Huth (1960) have been the first who observed synovial membrane submicroscopic structure in calf and lately Howlett (1974) who described differences in ultrastructure of this tissue in bulls under pathological conditions. 
These studies (and many others not mentioned here) on the synovial membrane of mammals and man (Horký 1981) stated that there are no differences in the fine structure of synovial membrane in different age groups and only small differences in the appearance of synovial membrane of various joints in man and other mammals.

\section{Materials and Methods}

Ultrastructural studies of the synovial membrane have been made on tissue samples obtained from 3 bovine adult individuals aged 3 to 5 years and 4 individuals aged 246 to 271 days after fertilization. Material was collected partly from the carpal, partly from hip joint for both light and electron microscopic histology.

The synovial membrane was taken behind the transient zone in different places on the perifery of the joint capsule. Tissue stripes of $1 \times 1 \times 2 \mathrm{~mm}$ were carefully cut out to keep at least a part of the subsynovial tissue in order to define the thickness and type of the synovial membrane.

These synovialis samples were immediately fixed in $4 \%$ glutaraldehyde in $0.1 \mathrm{M}$ phosphate buffer, pH 7.4 in two rinses for 60 and 180 minutes, then washed in three changes of $0.1 \mathrm{M}$ phosphate buffer, $\mathrm{pH} 7.4$ and post fixed in $\mathrm{OsO}_{2}$ in phosphate buffer, $\mathrm{pH} 7.4$ for 15 and 45 minutes. Dehydration proceeded in an acetone grading concentration $(25 \%-100 \%$ acetone) finished with two 30 minute rinses in $90 \%$ and $100 \%$ acetone. The infiltration was performed in a standard way, the material embedded in Durcupan ACM and polymerized at $60{ }^{\circ} \mathrm{C}$ in a thermostat for 3 days.

Ultrathin sections cut out on an Ultracut Reichert microtome were stained with lead citrate according to Reynolds or with $1 \%$ uranyl acetate followed by lead citrate. Sections thus obtained were studied and photographed with a Tesla BS 613 and Tesla BS 500 electron microscopes. From the embedded material also semithin sections were cut out for the light microscopy and stained with $1 \%$ methylene blue and $1 \%$ Azur II.

\section{Results}

\section{Ultrastructure of the Synovial Membrane}

The first part of this chapter gives a survey on the ultrastructure of cells of the synovial membrane and synovial matrix as well as on the formation of subsynovial tissue of adult individuals. In the second part similar structures of the synovial membrane in their early developmental period are dealt with.

\section{Submicroscopic Structure of Cells of the Synovial Membrane of Adult Individuals}

The surface of synovial membrane is usually formed by 1 to 4 layers of cells (Fig. 1,2). Their shape varies and forms a more or less compact layer but they are not tightly attached one to another as for example the epithelial cells. They emit several protrusions interconnected with one another. They are sporadically arranged in synovial matrix of the most of mammals (Langer and Huth 1960; Ghadially and Roy 1966; Bozděch and Horn 1970; Krey et al. 1976; Linck and Porte 1978; Okada et al. 1981; Horký 1981) while by rats for example matrix is reduced and the cells lean closely to one another (Roy and Ghadially 1967, Wassilev 1972, 1973, 1975). Our own observations on the cellular disposition of synovial membrane agrees with literary data of authors who observed parts of synovial membrane uncovered by a continuous layer of cells or only partly covered by their flat projections. In this way comes matrix into direct contact with the synovial fluid (Fig. 4, 5). According to Barland et al. (1962) cells of 
synovial membrane are usually classified as A and B type although there may be reservations to this division. Several authors use typization F, N, ER, V, F-M, $\mathrm{C}$ or I cells trying to express the tran ient form between the definitely formed types. We shall hold to the classical division.

\section{Ultrastructure of A-Cells}

Cells of the A type are less numerous in the cellular population of synovial membrane of adult bovine individuals. They occur mostly near the surface of synovial membrane (Fig. 1).

\section{Nucleus}

has usually oval shape, its nuclear envelope projecting against karyoplasma into shallow invaginations. Zonula nucleum limitans of about $0,1 \mu \mathrm{m}$ thickness is closely attached to its inner membrane. Chromatin is arranged into large karyosomes attached closely to intimal membrane of the nuclear envelope or leans to zonula nucleum limitans. This structure is interrupted in places of nuclear pores.

Nucleolus is usually of reticular type.

\section{Cytoplasm}

Granular endoplasmic reticulum occurs in the cytoplasm of A-cells in form of infrequent flattened cisternae to the surface of which ribosomes are attached.

Agranular endoplasmic reticulum is formed by single smooth sacs originating possibly from Golgi complex or from the splitted off folds of the cell membrane. Besides these folds vesicles of size 0.5 to $0.8 \mu \mathrm{m}$ appear in the cytoplasm of A-cells, containing material similar to the amorphous substance of synovial membrane (Fig. 1).

The Golgi complex is little conspicuous occupying only a small area in the cytoplasm of A-cells. There are some fine vesicles coming out of it.

Mitochondria have a standard structure reaching size of 0.1 to $0.5 \mu \mathrm{m}$ on cross sections. They are mostly of oval shape.

Ribosomes, in their majority, are attached to the membranes of the granular endoplasmic reticulum and only few of them can be found loosely placed in the cytoplasm.

Lysosomes occur regularly but few in number in the cytoplasm of A-cells. They have a standard shape and size (Fig. 1).

Centrioles did not occur in our material.

The cell membrane. The cytoplasm of A-cells penetrates into numerous and often long (some $\mu \mathrm{m}$ ) protrusions, surrounding (on the section) large vacuoles. Number of the pinocytotic vesicles is small.

Lipid droplets and glycogen are very rare in the cytoplasm of A-cells of the synovial membrane. They were found in our material only exceptionally.

Cytoplasmic fibrillar structures are represented as filaments of 3 to $5 \mathrm{~nm}$ thickness in varying amount. They are deposited perinuclearly in bundles between organellae. Their origin and function are similar to chondrocytes becoming a part of the intercellular substance. 


\section{Ultrastructure of B-Cells}

In comparison with A-cells are the synovial membranes in the cellular population represented in a greater amount, sometimes forming clusters (Fig. 2). They are placed on the surface as well as in deeper layers of the synovialis. On the section is their shape polygonal or rounded or cylindrically elongated.

Nucleus

has often a lobulous shape, its nuclear envelope projecting against karyoplasm into deep invaginations, so that even false nuclear inclusions may develop (Fig. 2). Zonula nucleum limitans is not developed. Chromatin is organised in a similar way into karyosomes at the nuclear envelope, nucleoli are usually of reticular type, but even nucleoli of the compact type could be observed.

Cytoplasm

There is a larger amount of granular endoplasmic reticulum in the cytoplasm of B-cells in comparison with A-cells. It has an appearance of short flattened cisternae situated mostly at the cell periphery. Some cisternae are wider at the ends (Fig. 2).

Agranular endoplasmic reticulum has the same arrangement and form as in A-cells.

The Golgi complex is formed by $3-4$ short cisternae and a large number of small vesicles. It is dispersed into several small fields in the cytoplasm (Fig. 2).

Mitochondria are smaller in comparison with A-cells and contain a dense matrix so that cristae are often difficult to identify.

Lysosomes in the cytoplasm of B-cells are difficult to prove as they practically do not differ from the secretion granules of B-cells.

Secretion granules are very numerous (Fig. 2, 3). They resemble dense bodies, their size reaching 0.2 to $0.6 \mu \mathrm{m}$, their shape is oval. They are demarcated by a smooth membrane and contain homogeneous electron dense substance.

Cell membrane has a small number of prominences reaching into the surrounding matrix. The protrusions on sections often enclose larger areas in between them, imitating so the larger vacuoles. Pinocytotic vesicles are few in number.

Lipid droplets and glycogen are, analogously to A-cells rarely to be found.

Cytoplasmic fibrillar structures in B-cells are localized mostly at their periphery, ev. in projections (Fig. 3).

\section{Synovial Matrix}

This term is commonly used to indicate the intercellular substance of the synovial membrane, which is composed of ground fibrillar and ground amorphous substance. In literature there is minimal attention given to this part of the synovial membrane, although several authors mention it.

Ground fibrillar substance is formed of two types of fibrillar structures. In the first place there are typical collagen fibrils 60 to $100 \mathrm{~nm}$ wide and some $\mu \mathrm{m}$ long, only seldom branching and showing periodicity which is characteristic for collagenous fibrils, that is about $64 \mathrm{~nm}$. The second type of fibrillar structures are aperiodic fibrils about $50 \mathrm{~nm}$ wide and $0.1 \mu \mathrm{m}$ long, sometimes even more. These fibrils occur in the dilated cisternae of the granular endoplasmic reticulum, in the ground cytoplasm between cellular organellae and perinuclearly in cells of A and B types. Ghadially and Roy (1966), Roy and Ghadially (1967), 
Wassilev (1972, 1975), Krey and Cohen (1973) described fibrillar structures of this appearance in cells of the synovial membrane in different mammals.

Ground amorphous substance into which the fibrillar component is inserted, is first of all formed, equally with other types of tissue, by a complex of protein-hyaluronic acid and sulphonated mucopolysaccharides. Both types of this substance are described in the electron microscope as fine granulated medium osmiophilic substance, deposited in area between the collagenous fibrils. It seems probable that both components, i. e. both the protein-hyaluronic acid complex and mucopolysaccharides migrate into the synovial fluid.

The arrangement of the intercellular substance, mainly of the fibrillar ground substance, differs on one hand in its direction from the surface into the deeper layers of the synovial membrane and depends on the amount and arrangement of synovial cells.

In section of the synovial membrane where the cells are placed in several layers over one another (Fig. 1,2) is the margin between the synovial membrane and the joint cavity formed only by synovial cells which are not covered by intercellular substance. The intercellular substance can communicate with the joint cavity only in short segments. It is different in those cases where cells of the synovial membrane are deposited on the surface only in one layer. Cells in these sections do not usually reach to the surface of the membrane and are covered over with a layer of intercellular substance of various thickness consisting mainly of aperiodic fibrils connected together by an amorphous component, represented by more compact granulated areas. The typical collagen fibrils occur in the superficial layer only in small number.

Underneath such formed surface, in the middle layer as well as in the deep one, in case of a layered synovial membrane typical collagen fibrils prevail, often arranged into bundles above the aperiodic fibrils. There is a small amount of the amorphous ground substance between the bundles of collagen fibrils.

Synovial membrane has a quite different appearance in sections which are not covered by cells, resp. when covered only by their thin projections. Here then (Fig. 4, 5) is the synovial membrane surface more or less smooth without any unevennes formed by synovial matrix, on surface of which viewing the joint cavity a distinct dense layer is seen. There is a larger amount of aperiodic filaments into which sporadic collagen fibrils penetrate (Fig. 4) from the depth. These filaments get thicker and form a distinct margin layer. Under thus formed surface disintegrated A-cells often occur. In parts where the synovial membrane is covered only by flat projections of synovial cells (Fig. 5), a thin layer composed of aperiodic filaments can be seen, where bundles of rough collagen fibrils passing in different directions can be found. Thus formed sections of the synovial membrane contain cells in deeper layers only sporadically (Fig. 5). Near to surface of the synovial membrane in adult individuals regularly thick walled vessels appear (Fig. 7).

\section{Submicroscopic Structure of Subsynovial Tissue}

Structure of the subsynovial tissue differs within the same joint due to various quantitative representation partly of cells partly of the ground fibrillar substance. According to these criteria it has been classified as fibrous, fibrous-lipid and lipidic subsynovial tissue. At present, according to new observations, it is divided into two types - fibrous and lipid (Jaffe 1972). With regard to the fact that no basal 
membrane has been proved in the synovial membrane of most mammals separating the cells of the synovial membrane from the structures deposited lower (Barland et al. 1962; Bozděch and Horn 1970; Horký 1981), the margin between the synovial membrane proper and subsynovial tissue is not distinct. The deep layer of the synovial membrane continues without a distinct margin into the subsynovial tissue. As a real margin between the two layers is considered that area where more or less typical fibrocytes, ev. macrophages are located under the A ev. B-cells of the synovial membrane and in a normal synovial membrane even some mast cells (Fig. 6).

The ground fibrillar substance is represented by strong bundles of collagenous fibrils with a typical periodicity passing in different directions, so that they may be followed both in the transversal and tangential as well as cross sections. No aperiodic fibrils were seen (Fig 6).

There is a variable amount of the ground amorphous substance among the bundles of collagen fibrils. In an electron microscope it has its characteristic appearance of irregularly arranged mesh-work of medium electron density. Its amount depends on the frequency of collagen fibrils and on their arrangement into bundles.

Submicroscopic Structure of the Synovial Membrane During the Fetal Period

The bovine synovial membrane has been well differentiated during the studied period. Similar to adult individuals, synovialocytes of A and B type, synovial matrix of the subsynovial tissue can be distinguished.

\section{Ultrastructure of A-Cells}

Similarly to the adult synovial membrane A-cells are less numerous elements in the cell population of a developing synovial membrane. They occur mostly near the surface of synovial membrane forming here an incomplete layer.

Nucleus

has mainly an elongated shape, nuclear envelope projects against karyoplasm into wide shallow invaginations (Fig. 9). A thin zonula nucleum limitants of no more than $0.1 \mu \mathrm{m}$ width leans to inner membrane of the nuclear envelope. Chromatin is arranged into a nearly continuous layer at the inner membrane of the nuclear envelope and into one-two larger karyosomes, so that the remaining area of the nucleus is strikingly light.

Nucleolus when found, has usually a reticular type.

Cytoplasm

Granular endoplasmic reticulum occurs in the cytoplasm of A-cells in a relatively small number as short, flat, only sporadically widely dilated cisternae containing material of medium electron density. Cisternae are rich in ribosomes (Fig. 9).

Agranular endoplasmic reticulum is present in a great amount in the cytoplasm of A-cells. It appears as minute vesicles of $0.02 \mu \mathrm{m}$ size dispersed in the cytoplasm (Fig. 9). These probably may be small Golgi vesicles as there are no pinocytotic vesicles formed in a larger number on the cell membrane. 
Golgi complex has a little distinct structure in the cytoplasm of A-cells. It occupies only a small field and is not visible in all the sections.

Mitochondria are of standard structure and size as well as ribosomes which are attached mostly to the membrane of the granular endoplasmic reticulum.

Lysosomes reach only size of 0.2 to $0.3 \mu \mathrm{m}$ and in the cytoplasm of A-cells are regularly present in a small number.

Centrioles and cilia. We have not found them in the A-cells.

Cell membrane of A-cells projects in a small number of short vesicles into the next intracellular substance. There is a small number of pinocytotic vesicles.

Lipid droplets and glycogen have not been observed in our material.

Cytoplasmic fibrillar structures have an identical appearance to that of A-cells in an adult cartilage. They are mostly perinuclearly deposited forming a nearly continuous margin around the nucleus (Fig. 9).

\section{Ultrastructure of B-Cells}

In the followed period is this type of cells in the synovial membrane more often represented, but accumulation of B-cells as it is to be seen in the synovialis of adult individuals, has not been found.

Nucleus

is mostly oval (Fig. 9, 11), the nuclear envelope only rarely forming wide shallow invaginations giving nucleus a crescent shape (Fig. 10). Chromatin is crowded into several karyosomes at the nuclear membrane or into a nearly continuous margin with light canals in nuclear pores (Fig. 9, 10). Zonula nucleum limitans is narrow, sometimes difficult to identify.

Nucleolus has a constant structure in sections through nucleus. Most of these are nucleoli of reticular type (Fig. 10).

Cytoplasm

In comparison with A-cells is the granular endoplasmic reticulum present in the cytoplasm of B-cells in a larger amount. It appears as short flat cisternae deposited perinuclearly among organellae (Fig. 9, 10) as well as in cytoplasmic projections (Fig. 10,11). It comes often to dilation in the projections of cisternae of the granular endoplasmic reticulum (Fig. 11), its widened areas containing medium osmiophilic, fine granular material.

Agranular endoplasmic reticulum in B-cells is not as developed as it is in A-cells. It appears as single vesicles in the cytoplasm dispersed without any conspicuous topographic relations to other cell organellae.

Golgi complex is similarly to the cytoplasm of A-cells poorly developed, does not occupy larger fields and is composed of some short flat cisternae and minute vesicles of medium osmiophilic material (Fig. 9.).

Mitochondria have usually an elongated shape and occur perinuclearly as well as in the projections (Fig. 10,11) between the widened cisternae of the granular endoplasmic reticulum and filaments.

Ribosomes, in the most part, are attached to membranes of granular endoplasmic reticulum (Fig. 9-12). Only a small number is loosely situated in the cytoplasm, forming there rosette-like polysomes (Fig. 10).

Lysosomes, analogically to A-cells, are present in a small number (Fig. 9, 10) having similar appearance and size. 
Centrioles and cilia have been observed in some cases in B-cells (Fig. 10, 12).

Cell membrane of B-cells makes often long and strong prolongations (Fig. 10, 11), which get wider to the end. These prolongations contain cisternae of granular endoplasmic reticulum, fibrillar structures and mitochondria. In their area is the cell membrane descending into a distinctly great amount of pinocytotic vesicles which pass into cytoplasm (Fig. 11). The B-cells are lined by an uncomplete basal membrane (Fig. 10, 11, 12).

Secretion granules are a distinct sign of the cytoplasm of B-cells. Their size is about 0.4 to $0.8 \mu \mathrm{m}$ (Fig. 9,12$)$ and in the cytoplasm they are present in various number. They are defined on the surface by a single membrane and contain a fine granular dense substance.

Cytoplasmic fibrillar structures are less distinct in the cytoplasm of B-cells than in A-cells. They occur as smaller bundles of aperiodic fibrils mostly in the cytoplasmic prominences between organellae (Fig. 11).

For the first time during the studied period we observed here collagen fibrils extruding from the cytoplasm into the extracellular area (Fig. 12). We observed this phenomenon only in the area of cytoplasmic protrusions where a series of collagen fibrils penetrates from the outer layer of cytoplasm through the cell membrane and where even collagen fibrils are intracytoplasmatically demonstrated.

\section{Discussion}

According to results of our study the organisation of bovine synovial membrane is rather similar to that of synovialis in other mammals (Langer and Huth 1960; Barland et al. 1962; Ghadially and Roy 1966; Bozděch and Horn 1970; Cutlip and Cheville 1973; Fell et al. 1976; Krey et al. 1976; Linck and Porte 1978; Okada et al. 1981; Horký 1981) except in rats, where Roy and Ghadially (1967) and especially Wassilev (1972, 1973, 1975) describe accordingly the synovial membrane as strinkingly clustered with cells, the synovial matrix being reduced at the same time.

Whereas in all the investigated material of mammalian species B-cells mainly occured in the synovial membrane separately dispersed among the predominating A-cells, we observed a rather large occurrence of B-cells clustered in the bovine adult individuals synovial membrane. These clusters were not observed in the synovial membrane of fetuses.

A striking sign of B-cells in both age categories is the presence of secretory granules. These granules described already earlier Wyllie et al. (1964), Ghadially and Roy (1969), Linck and Porte (1978); they named them by different terms and also conceptions on their origin and volume greatly differed. Linck and Porte (1978) and especially Okada et al. (1981) published studies showing that the granular endoplasmic reticulum and Golgi complex, that is cell organellae, specific function of which in the process of synthesis and ev. extrusion of secretion has been proved also in other cells types, take a great part on the origin of secretory granules. Okada et al. (1981) proved in their study that these granules do not contain acid phosphatase but mucopolysaccharides and glycoproteins attached to the proteins, proving it by digestion of proteins. Nevertheless their extrusion into the synovial fluid has not been proved and their participation in the process of lubrication of the joint remains so far as hypothesis.

In works of Linck and Porte (1978), Okada et al. (1981)we found again the 
confirmation of our already earlier stated observation (Horký et al. 1975) of the possibility of cell transformation into B-cells type whose appearance and representation changes in dependence on the actual state of the synovial membrane. Linck and Porte (1978) mention in their work that this phenomenon represents only functional plasticity of the synovial membrane but does not mean loss of the cellular function. There are also differences in the submicroscopical structure of synovialocytes in dependence on mammalian species, so that for example bovine B-cells differ in some details from those of the same type in synovial membrane of sheep, as Cutlip and Cheville (1973) describe.

There is little attention given to cytoplasmic fibrillar structures regularly found in adult individuals as well as in fetuses in the B-cell of cytoplasm. Diverse in species is then occurrence of desmosomes and of basal membrane (W assilev 1972; Linck and Porte 1978) which these authors found well developed in mice and rats. Desmosomes did not occur in our material between the cells and we could find basal membrane only sporadically in some sections along the basal membrane.

In view of our opinion is very interesting the morphologic proof of transport of collagen fibrils through cell membrane of B-cell in a fetal synovial membrane and their intracytoplasmatic deposition. A similar finding was not stated in literature up to now.

The surface of synovial membrane and of subsynovial tissue of the followed fetal period does not differ from adult individuals. We can state analogically sections of synovial membrane which are not covered by cells and where the ground amorphous substance is in direct contact with the synovial fluid. We already described a similar arrangement by man (Horký et al. 1975; Horký 1981).

\section{Ultrastruktura synoviální membrány skotu v ontogenesi}

Ke studiu ultrastruktury synoviální membrány skotu byly odebrány vzorky této tkáně od 3 dospělých jedinců ve stáři 3-5 let a od 4 jedinců ve stáŕí 246 až 271 dnů po oplození. Materiál byl odebrán jednak z karpálního, jednak kyčelního kloubu a to jak pro světelnou, tak elektronově mikroskopickou histologii.

Synoviální membrána se skládá ze specificky modifikovaných buněk, které na podkladě studia jejich submikroskopické stavby můžeme diferencovat na A a B typ a $\mathrm{z}$ hmoty mezibuněčné. Pod vlastní synoviální membránou je uložena subsynoviální tkáň.

V synoviální membráně dospělých jedinců vytvářejí A buňky téměř souvislý pokryv a mezi nimi jsou ve shlucích uloženy buňky $\mathrm{B}, \mathrm{v}$ jejichž cytoplasmě jsou uložena četná sekretorická granula a ve výběžcích svazky cytoplasmatických filament. Mezi buňkami se nevytvářeji spoje typu desmosomu a rovněž chybí bazální membrána. Intercelulární prostory jsou vyplněny základní hmotou amorfní s převahou aperiodických fibril.

Synoviální membrána $\mathrm{v}$ období fetálnim má obdobné uspořádání. $\mathrm{B}$ buňky jsou početné, ale nevytvářejí shluky. Množství organel podílejících se na proteosyntéze je ve srovnání s dospělými jedinci větší, což svědčí o jejich aktivitě. V těchto buňkách jsme prokázali kolagenní fibrily jednak intracytoplasmaticky, jednak prostupující přes buněčnou membránu.

Jak u dospělé, tak fetální synoviální membrány jsme pozorovali na povrchu úseky nekryté buňkami, takže mezibuněčná hmota je $\mathrm{v}$ přímém kontaktu s kloubní dutinou. 


\section{Ультраструкгура синовиальной мембраны крупного рогатого скота в он тогенезе}

С целью изучения ультраструктуры синовиальной мембраны крупного рогатого скота проводили отбор образцов данной ткани у трех взрослых животных в возрасте $3-5$ лет и у четырех животных в возрасте $246-271$ день после оплодотворения. Материал отбирали из запястного, а также тазобедренного суставов для свеговой и элекгронно-микроскопической гистологии.

Синовиальная мембрана состоит из специфически модифицированных клеток, которые можно на основе изучения их субмикроскопического строения разделить на типы А и Б и межклеточную массу. Под собственно синовиальной мембраной расположена субсиновиальная ткань.

На синовиальной мембране взрослых животных клегки А образуют почти сплошное перекрытие и между ними в скоплениях расположены клетки Б, в цитоплазме которых находятся многочисленные секрегорные гранули и в отростках - пучки цитоплазматических филаменгов. Между клетками не образуются соединения типа десмосомы и отсутствуег также базальная мембрана. Межклеточное пространство заполнено основной массой, аморфной, с преобладанием апериодических фибрилл.

Синовиальная мембрана в зародышевый период отличаегся подобного рода структурой. Клегки Б многочисленные, однако они не образуюг скопления. Число органелл, принимающих участие в прогеосинтезе по сравнению со взрослыми животными больше, что свидегельствуег об их активности. В упомянутых клетках были выявлены клейдающие фибриллы интрацитоплазматически, а также проникающие через клегочную мембрану.

У взрослой и зародышевой синовиальной мембран на поверхности наблюдались участки, не покрытые клегками, следовательно, межклегочная масса находилась в непоскедственном соприкосновении с полостью сустава.

\section{References}

BARLAND, P. - NOVIKOFF, A. B. - HAMERMAN, D.: Electron microscopy of the human synovial membrane. J. Cell Biol., 14, 1962, 207-220.

BOZDĚCH, Z. - HORN, V.: Die funktionelle Regeneration nach Synovektomie im Experiment. Z. Ortop., 108, 1970: $98-104$.

CUTLIP, R. C. - CHEVILLE, N. F.: Structure of synovial membrane of sheep. Am. J. Vet. Res., 34, 1973: 45-50.

FELL, K. B. - GLAUERT, A. M. - BARRAT, M. E. J. - GREEN, R. E.: The pig synovium. I. The intact synovium in vivo and in organ culture. J. Anat., 122, 1976: 663-680.

GHADIALLY, F. N. - ROY, S.: Ultrastructure of rabbit synovial membrane. Ann. Rheum. Dis., 25, 1966: 308-326.

HORKYY, D. - BOZDĚCH, Z. - HORN, V.: Ultrastructure of the synovial membrane and the joint cartilage in haemophilia observed in a transmission and scanning electron microscope. Acta Fac. Med. Univ. Brun., 52, 1975: 195-210.

HORKÝ, D.: Submicroscopic structure of the human synovial membrane. Acta Vet. Brno, 50, 1981: $3-25$.

HOWLETT, C. R.: Pathology of coxofemoral arthropathy in young beef bulls: ultrastructure of synovium. Pathology, 6, 1974: 19-28.

HUNTER, W.: see STONE, K. In: Disease of the joints and rheumatism. London: Heinemann 1947.

JAFFE, H. L.: Metabolic, degenerative and inflammatory diseases of bones and joints. München Berlin - Wien, Urban and Schwarzenberg, 1972.

JOHANSSON, H, E. - REJNÖ, S.: Light and electron microscopic investigation of equine 
synovial membrane. A comparison between healthy joints with intraarticular fractures and osteochondrosis dissecans. Acta Vet. Scand., 17, 1976: 153-168.

KREY, P. R. - COHEN, A. S.: Fine structural analysis of rabbit synovial cells. I. The normal synovium and changes in organ culture. Artritis Rheum., 16, 1973: 324-340.

KREY, P. R. - SCHEINBERG, M. A. - COHEN, A. S.: Fine structural analysis of rabbit synovial cells. II. Fine structures and rosetteforming cells of explant and monolayer cultures. Arthritis Rheum., 19, 1976: 581-592.

LANGER, E. - HUTH, F.: Untersuchungen über den submikroskopischen Bau der Synovial Membrane. Z. Zellforsch., 51, 1960: 545-549.

LINCK, G. - PORTE, A.: B-cells of the synovial membrane. I. A comparative ultrastructural study in some mammals. Cell Tiss. Res., 187, 1978: 251-261.

OKADA, Y. - NAKANISHI, I. - KAJIKAWA, K.: Secretory granules of B-cells in the synovial membrane. An ultrastructural and cytochemical study. Cell Tiss. Res., 216, 1981: $131-141$.

ORYSCHAK, A. F. - GHADIALLY, F. N.: Evolution of aurosomes in rabbit synovial membrane. Virchows Archiv A, Zellpathol., 20, 1976: 29-29.

ROY, S. - GHADIALLY, F. N.: Ultrastructure of normal rat synovial membrane. Ann. Rheum. Dis., 26, 1967: 26-38.

STONE, K.: Diseases of the joints and rheumatism. Heinemann, London, 1947.

WASSILEV, W.: Electron microscopical studies on the development of synovial cells in the knee joint of the rat. Verh. Anat. Ges., 67, 1972: 387-392.

WASSILEV, W.: Ultrahistochemical localization of adenosine triphosphatase activity in the synovial membrane of rats. Histochemie, 37, 1973: 113-117.

WASSILEV, W.: Changes in the ultrastructure of the synovial membrane during growth and aging. Verh. Anat. Ges., 69, 1975: 427-431.

WYLLIE, J. C. - MORE, R. H. - HAUST, M. D.: The fine structure of normal guinea-pig synovium. Lab. Invest., 13, 1964: 1254-1263. 